\title{
“INFELIZMENTE SER FELIZ TEM SEU PREÇO”: SAÍDA DO ARMÁRIO E DISCURSO DE RESISTÊNCIA DE UM MILITAR GAY
}

\author{
Flávia Correia Lima Huber Costa*
}

\section{Resumo}

Nesse artigo será analisado o discurso de resistência de um militar gay com o objetivo de discutir as estruturas culturais que atuam da construção da homofobia no Exército. A análise se apoia no arcabouço teórico da análise de narrativa, dialogismo, masculinidade hegemônica e epistemologia do armário. Pretende-se problematizar o embate entre a aceitação legal da presença de homossexuais nos quartéis e a rejeição por parte de colegas de farda.

\section{Palavras-chave}

Homofobia. Militar. Armário. Discurso. Masculinidades.

\section{1) Introdução}

Bial: - Entre as mudanças importantes realizadas sob o seu comando esteve a inclusão de mulheres nos cursos militares combatentes. Quando vai chegar a vez dos gays e dos transexuais?

General Villas Boas: - É isso, o Exército segue a legislação, a lei. E já temos no Exército. Tem inclusive transexuais, tem pessoas casadas com o mesmo sexo.

Bial: - Mesmo em cursos de combatentes? (Cara de surpresa)

General Villas Boas: - Também. Também mesmo nesses cursos. Você vê que existem, né, no Exército e não se ouve falar, né? Que tenha causado algum problema, enfim... Porque a coisa tá assimilada com naturalidade. E tá se cumprindo a lei.

Bial: - Porque pra mim, eu imagino isso; um baita de um choque cultural, porque o Exército, as Forças Armadas em geral, são instituições com um machismo milenar, né? Faz parte, né? (risos)

General Villas Boas: - Machismo milenar, é verdade. (risos) Bom, é... Mas veja bem, de certa forma é um choque. E a sociedade em geral não assimilou isso bem, né? Então, é natural que dentro da Força, né, isso ocorra, mas é... Nós temos o Regulamento Disciplinar, que inibe que isso ocorra. Eu não vou dizer que eventualmente não ocorra algum problema, né, Bial? Onde há seres humanos, enfim... Mas isso tá ocorrendo com absoluta naturalidade.

Bial: - Mas então, como postura, como posição institucional, pode? Pode gay, pode transexual?

General Villas Boas: - Pode.

Bial: - Em qualquer curso militar combatente...

General Villas Boas: - Pode sim.

\footnotetext{
* Oficial do Exército Brasileiro, Mestre em Estudos da Linguagem pela PUC-Rio, atualmente é doutoranda
} pelo mesmo programa. 
Bial: (Cara de surpresa) - Nada como um dia após o outro!

General Villas Boas: - Não é?

Bial: - Incrível!

Programa "Conversa com Bial" em 19/set/2017

Em setembro de 2017, numa conversa bastante descontraída durante o programa da Rede Globo Conversa com Bial, o General Villas Boas, então comandante do Exército Brasileiro, respondeu a diversos questionamentos, inclusive sobre a presença de gays e transexuais na caserna. A interação entre o comandante e o jornalista revela muito sobre o ideal da masculinidade discursivamente construído ao logo da história do Exército de Caxias.

No excerto selecionado da entrevista, o próprio General - ao afirmar que ainda ocorrem problemas com a presença de gays na Força por causa de algumas pessoas que também ocupam esse espaço - indica como a cultura da homofobia existente no Exército Brasileiro foi construída e consolidada ao longo de décadas de um discurso heterossexista. Considero aqui a cultura como "um conjunto de repetição e de naturalização de comportamentos sociais diante de determinado grupo" (JESUS, 2018, p. 67). No caso dos militares que se identificam como gays, podemos afirmar que eles são as grandes vítimas do tal "machismo milenar" descrito pelo apresentador, a despeito das leis que autorizam tanto a união civil, quanto o casamento entre pessoas do mesmo sexo no país e nas Forças Armadas.

O espanto do apresentador sobre o posicionamento do general indica a normalização do ideal da masculinidade hegemônica (CONNELL e MESSERSCHMIDT, 2013), que se apoia em certos estereótipos de força física e emocional, resistência e comando, coragem e combatividade. Em oposição a tais signos, se encontram outros estereótipos que associam identidades gays a sensibilidade, fragilidade, vaidade e fraqueza. O resultado discursivo de tais concepções simbólicas sedimenta a ideia segundo a qual o homem gay não possui os atributos necessários para a carreira militar.

O simples fato de o comandante falar publicamente sobre a presença de militares homossexuais ${ }^{1}$ no Exército Brasileiro já é um indício do avanço institucional que vem ocorrendo em relação à essa questão nos últimos anos nas Forças Armadas. Vale ressaltar

\footnotetext{
${ }^{1} \mathrm{O}$ termo "homossexual" é utilizado aqui para fazer referência a um indivíduo que se identifique como gay ou lésbica. Não há qualquer pretensão em essencializar identidades.
} 
que em 2011, enquanto ainda era o Comandante do Exército, o General Enzo Martins Peri afirmou em uma entrevista à revista Veja que não havia homossexuais nas fileiras das Forças Armadas Brasileiras - negando a fluidez e a diversidade de gêneros e sexualidades que sempre existiram na caserna. Quatro anos mais tarde, em outubro de 2015, por ordem do próprio General Villas Boas, todas as organizações militares do Exército Brasileiro receberam um documento tratando da obrigatoriedade do reconhecimento, como entidade familiar, da união de pessoas do mesmo sexo, independente da edição de regulamentos. Esse foi um passo crucial para a garantia de direitos de militares homossexuais. No entanto, como os participantes da entrevista transcrita aqui comentam, ainda perdura o tal "machismo milenar" nos discursos que circulam nos quartéis. Persiste a intolerância, por parte de muitos colegas de farda, à presença de militares cuja identidade ${ }^{2}$ fuja da norma heterossexual.

Em meu estudo anterior (COSTA, 2015), baseado em narrativas de discriminação homofóbicas sofridas por militares homossexuais, foi observado que, desde a escola de formação, instrutores encorajam os próprios colegas a excluírem socialmente gays, ladrões e drogados da turma. Um dos militares entrevistados revelou que, no ano de 2008, ao ter sua sexualidade exposta após ter sido fotografado na Parada Gay de São Paulo por um dos principais jornais do país, foi punido com prisão por "decoro da classe". Ou seja, na época, o seu comportamento foi entendido como vexatório para a instituição. Hoje, pouco mais de uma década após o episódio, o Exército Brasileiro tem se adequado às novas leis e busca institucionalmente eliminar a discriminação contra homossexuais. No entanto, mudar o discurso hegemônico, construído e mediado pelo poder heteronormativo, que nega as diversas ramificações de expressividade sexual, ainda é um desafio longe de ser alcançado - afinal, o discurso carregado de concepções ideológicas não é transformado com uma simples alteração de regras e legislações.

No contexto militar, a aceitação social de quem foge à figura do homem masculinizado esbarra em preconceitos da sociedade que se atualizam na caserna (COSTA e BIAR, 2015). Ainda vivemos um cenário de discriminação sexual, protagonizado por indivíduos cujos valores morais afastam o gay da possibilidade da

\footnotetext{
${ }^{2} \mathrm{O}$ conceito de identidade nesse trabalho é entendido como um conjunto simbólico constante do ser humano em si mesmo, e do ser com o outro. A posição do indivíduo na sociedade é determinada através dessa relação (HALL, 1992). Ou seja, as identidades não são qualidades inerentes ao ser humano, e sim concebidas na interação com outras pessoas.
} 
convivência social livre de julgamentos. Para muitos militares, a homossexualidade ainda é sinônimo de imoralidade e anormalidade. Faz-se relevante, portanto, repensar certas práticas discursivas, pois "quando os participantes se engajam no discurso agem tanto sobre significados que são sócio historicamente dados, (...) como também sob significados que eles próprios geram nas práticas discursivas em que se localizam" (MOITA LOPES, 2004, p.7). Nessa direção, compartilho da ideia de Moita Lopes (2004, p.12), baseado no pensamento de Foucault, sobre a existência de um 'regime de verdade' que bane o debate sobre homoerotismo das instituições disciplinares, tais como o próprio Exército Brasileiro.

Tendo como base o cenário até aqui descrito, o objetivo desse trabalho é discutir a construção do discurso de resistência de um Oficial gay, que decidiu sair publicamente do armário em uma rede social após ter visto sua intimidade ser invadida e exposta em grupos de conversas de militares pelo Whatsapp que intencionavam humilhá-lo para toda Força. Para tanto, será percorrido um caminho que leva em conta a construção do discurso homofóbico até chegar à narrativa de resistência do militar. Primeiramente, foi apresentado o trecho de uma entrevista onde se observa concepções de paisanos a respeito do tema nas Forças Armadas (representada pelo apresentador Bial) e a voz oficial da instituição (representada pelo General Villas Boas). Serão analisadas capturas de telas (prints) ${ }^{3}$ de grupos de Whatsapp formados por militares, que indicam como a cultura de homofobia é dialogicamente construída e retroalimentada no meio militar. Tais prints ilustram o processo que levou o oficial a posicionar-se publicamente após muitos anos em silêncio e, até mesmo, negando sua sexualidade. Por fim, será feita a análise de uma postagem pública (de 12 de março de 2019) do militar em questão na rede social Facebook, que simboliza uma grande saída do armário.

A discussão se dá através das lentes da análise de narrativa (LABOV e WALETSKY,1968; LABOV, 1972; BASTOS, 2004; BASTOS e BIAR, 2015) e dos conceitos de heteronormatividade (BORRILLO, 2010; LOURO, 2000), masculinidade hegemônica (CONNELL e MESSERSCHMIDT, 2013), dialogismo (BAKHTIN, 1979) e epistemologia do armário (SEDGWICK, 2007).

\section{2) O discurso dialógico da heteronormatividade e o armário gay na caserna}

\footnotetext{
3 As capturas de tela foram disponibilizadas por militares membros de tais grupos de Whatsapp. Por questões de ética, os nomes dos grupos, bem como dados dos participantes das conversas, foram omitidos.
} 
A palavra "heteronormatividade", que possui etimologia grega (hétero diferente) e latina (norma - esquadro), designa situações nas quais orientações sexuais que fujam do padrão aceito socialmente como normal e natural - isto é, a norma heterossexual -, sejam marginalizadas, estigmatizadas e perseguidas através de práticas sociais e políticas. A crença de que o ser humano deve se encaixar no binarismo sexual e de que as relações sexuais normais e aceitáveis são aquelas praticadas por um indivíduo do sexo masculino com outro do sexo feminino normatizam a heterossexualidade como sendo a única orientação legítima e admissível. De acordo com o princípio da heteronormatividade, um indivíduo deveria se enquadrar dentro das normas sociais masculinas ou femininas.

Borrillo (2010) define heteronormatividade como um modelo de sexualidade que seria superior às demais. De acordo com o autor:

\begin{abstract}
a heterossexualidade aparece assim como o padrão para avaliar todas as outras sexualidades. Essa qualidade normativa - e o ideal que ela encarna - é constitutiva de uma forma específica de dominação, chamada heterossexismo, que se define como a crença na existência de uma hierarquia das sexualidades, em que a heterossexualidade ocupa a posição superior. Todas as outras formas de sexualidade são consideradas, na melhor das hipóteses, incompletas, acidentais e perversas; e, na pior, patológicas, criminosas, imorais e destruidoras da civilização (2010, p.31).
\end{abstract}

O conceito de heteronormatividade para Louro (2000) abarca não apenas a questão de gênero, mas de raça e classe social também, naturalizando o homem branco, heterossexual de classe média urbana e cristão como uma identidade de referência social. Qualquer identidade que fuja desta identidade padrão e "não-problemática", torna-se uma identidade marcada. Segundo Louro, a identidade referência torna-se invisível, pois não precisa ser explicada. Assim, podemos dizer que causaria estranheza caso alguém se apresentasse e dissesse "sou heterossexual".

Quaisquer outras formas de ser que fujam à norma tornam-se marcadas, contrariando aquilo que é esperado socialmente. Outro aspecto relevante apontado pela autora é o fato de uma identidade que foge aos padrões culturalmente estabelecidos ser "representada não apenas por comparação à identidade hegemônica, mas a partir de um olhar hegemônico, daí que, muitas vezes, a identidade marcada não pode falar por si mesma" (LOURO, 2000, p. 68). 
A naturalização da identidade heterossexual impõe aos indivíduos uma constante cautela a respeito de suas performances sociais e sexuais para que sejam aceitos e categorizados como normais. Segundo Louro,

a vigilância volta-se, então, explicitamente, para os corpos. Uma vigilância que é exercida não somente a partir do exterior, da obediência às regras, aos preceitos ou aos códigos, mas que é exercida pelo próprio indivíduo que, precocemente, aprende a se examinar, controlar, governar (2000, p. 69).

A homofobia no meio militar apoia-se em certos estereótipos que equacionam, em especial - mas não exclusivamente -, o homem militar aos signos da chamada masculinidade hegemônica (CONNELL e MESSERSCHMIDT, 2013). De acordo com Connel e Messerschmidt, (2013, p. 245), a masculinidade hegemônica é certamente normativa, pois "incorpora a forma mais honrada de ser um homem, ela exige que todos os outros homens se posicionem em relação a ela". Ou seja, a masculinidade não determina uma única forma de "ser homem", mas sim a maneira como os homens se posicionam através de práticas discursivas. Connel e Messerschmidt afirmam que:

a masculinidade não é uma entidade fixa encarnada no corpo ou nos traços da personalidade dos indivíduos. As masculinidades são configurações de práticas que são realizadas na ação social e, dessa forma, podem se diferenciar de acordo com as relações de gênero em um cenário social particular (2013, p. 250).

A heteronormatividade na caserna ainda é tão intensa, que a despeito da mudança de legislações e determinações institucionais, descobrir que um colega de farda é gay é motivo de exaltação nos quarteis. Persistem, nas instituições militares, os padrões específicos de masculinidade hegemônica que costumam ser dominantes, mas têm se tornado cada vez mais problemáticos (CONNELL e MESSERSCHMIDT, 2013).

Quanto a revelar-se gay na caserna, vale ressaltar que o processo de visibilidade e enfrentamento de possíveis consequências de uma saída do armário, diante de algumas ou várias pessoas (SEFFNER e DUARTE, 2015), ainda é problemático e contingencial. O militar gay é constantemente empurrado para dentro do armário através de um discurso dialogicamente construído (BAKHTIN, 1979) sobre a incompatibilidade da profissão com qualquer orientação homoerótica. Esse discurso que ridiculariza o gay, reforça a heterossexualidade como padrão de normalidade e, portanto, única forma aceitável de viver. Vale lembrar que discurso aqui é entendido como "uma prática social que define 
nossas relações com o outro e nossos posicionamentos sociais" (JESUS e LIMA, 2017, p. 77).

Não há discurso ingênuo ou livre de posicionamentos ideológicos. Portanto, existe sempre uma dialogização interna da palavra (BAKHTIN, 1979), ou seja, todas as palavras são sempre perpassadas pela palavra do outro. O enunciador quando constitui seu discurso leva sempre em conta outros discursos que, por sua vez, estão presentes em sua enunciação. $\mathrm{O}$ enunciado não existe fora das relações dialógicas e carrega ecos e lembranças de outros enunciados, ocupando assim, uma posição na esfera de comunicação. Deste modo, todo discurso é atravessado pelo discurso do outro. E são essas relações de sentido, que se estabelecem entre os enunciados, que Bakhtin vai chamar de dialogismo.

Para Fabrício (2006, p. 48), a linguagem é na verdade uma prática social. Assim, o estudo da linguagem nos permite entender "a sociedade e as culturas das quais ela é parte constituinte e constitutiva". A autora alega que nossas práticas discursivas refletem "escolhas (intencionais ou não) ideológicas e políticas, atravessadas por relações de poder, que provocam diferentes efeitos no mundo social". Na mesma linha de pensamento, Jesus (2017, p.73), apoiado em Foucault, afirma que "é pelo discurso que elegemos a maneira de construir sentidos que estão em nossa órbita - por meio dele, evidenciamos as diferenças, criamos símbolos de unidades e de identificação coletiva. Se, às vezes, apagamos vozes, não raro eternizamos outras". Portanto, quando piadas que ridicularizam identidades gays são legitimadas e mensagens em grupos de redes sociais expondo o colega de profissão são compartilhadas, outras identidades, cuja performance identitária não esteja de acordo com o conjunto de prescrições sociais da heteronormatividade, são desencorajadas a sair do armário e viver livremente. Ou seja, é como se fosse dado um alerta avisando que qualquer um que ouse sair do armário, será exposto e humilhado perante toda a sociedade. E é no discurso que construímos essas relações de poder que determinam os lugares ocupados pelas identidades hétero e homossexuais nos quartéis.

A questão do armário como um dispositivo que regula a vida social do indivíduo homossexual é explicada por Sedgwick (2007) ao descrever a epistemologia do armário. Segundo a autora, existe uma concepção socioculturalmente construída de que gays e lésbicas possuem uma orientação sexual que deve ficar em segredo - ou não -, conforme os interesses da sociedade. Isto é, o armário é um instrumento de regulação não só de pessoas LGBT, mas também de pessoas que se identificam como heterossexuais, pois 
valores hegemônicos da heteronormatividade conferem aos heterossexuais maior visibilidade e privilégios na sociedade.

O armário gay não é uma característica apenas das vidas de pessoas gays. Mas, para muitas delas, ainda é a característica fundamental da vida social, e há poucas pessoas gays, por mais corajosas e sinceras que sejam de hábito, por mais afortunadas pelo apoio de suas comunidades imediatas, em cujas vidas o armário não seja ainda uma presença formadora. (SEDGWICK, 2007, p.22).

Ainda de acordo com Sedgwick, a "revelação do segredo" não destrói a questão ideológica que coloca o armário gay como característica fundamental da vida social. Conforme afirma a autora, até mesmo entre as pessoas mais assumidamente gays, há pouquíssimas que não estejam no armário com alguém, seja no âmbito pessoal, profissional, econômico ou institucional. Portanto, é possível assegurar que a epistemologia do armário foi responsável, em grande parte, pela cultura e identidade gay ao longo dos séculos.

Na mesma linha de pensamento, Cristóvão (2015, p.33) afirma que o armário sintetiza as relações entre ocultamento e delimitação, ou seja, "ao mesmo tempo que guarda em si a ideia de esconderijo da homossexualidade, a metáfora do armário também estabelece um controle da sexualidade como um todo". Assim sendo, entendemos que quando um militar é alvo de exposição vexatória em grupos de redes sociais, o que está, na verdade, acontecendo é uma pressão para que esse sujeito permaneça em seu armário para que não cause constrangimento e vergonha para toda a classe militar. Caso ouse enfrentar a fúria dos guardiões da heterossexualidade, será exposto em praça pública para que outros não se atrevam a fazer o mesmo. E dentro do mesmo ciclo vicioso, militares homossexuais são desencorajados a abrir as portas de seus armários por medo de retaliação pessoal e profissional. Como resultado, durante esse processo, ocorre o privilégio da norma identitária heterossexual e a exclusão dos diferentes (JESUS e LIMA, 2017).

\section{3) Narrativas}

Contar histórias talvez seja a maneira mais comum que as pessoas encontram para dar significado a suas experiências, reivindicar identidades e organizar sua vida (BASTOS, 2004). Boa parte de nosso cotidiano consiste em contar histórias e ouvir e ler as histórias de outras pessoas. A narrativa pode ser entendida, tradicionalmente, como 
uma forma de recapitular experiências passadas. Mas afinal, o que são essas histórias? Como elas constituem nossas vidas? E por que elas são importantes? Na verdade, as narrativas funcionam como "uma forma de organização básica da experiência humana, a partir da qual se pode estudar a vida social em geral” (BASTOS, 2004, p.119).Dessa forma, a narrativa passa a ser vista como uma construção social e não mais como uma representação do que aconteceu. Atuam nessa construção o filtro afetivo que guia a lembrança, as especificidades da situação de comunicação em que a narrativa é contada e a ordem sociocultural mais ampla (BASTOS, 2004).

A narrativa propicia ao indivíduo um entendimento a respeito de suas experiências através da construção de um mundo para o qual ele traz outras pessoas em relação às quais ele se posiciona. Dessa forma, as narrativas, conforme dito anteriormente, podem ser definidas como uma prática verbal básica e específica de se estruturar a experiência humana, que tem sido entendida como um lugar privilegiado para se estudar a vida em sociedade (BASTOS, 2004; BASTOS e BIAR, 2015). Isso se dá pelo fato de que ao contar histórias, as pessoas se engajam em um tipo de atividade interpretativa que dá forma, sequência e sentido a situações passadas, construindo sentidos sobre si mesmos, outras pessoas, objetos e ações do mundo social, sempre em relação a certos padrões culturais e finalidades interacionais determinados no contexto em que se encontram.

Os primeiros estudos de Labov e Waletsky (1968) e Labov (1972) consagram a pesquisa sobre narrativas orais. Para os autores, o requisito básico de sua construção é a referência a um evento extraordinário, isto é, uma narrativa precisa exibir um motivo claro para ser contada. Isto é o que Labov chama de ponto da narrativa. A estrutura narrativa é identificada pelos autores a partir de características bem definidas, que relacionam sequências verbais a sequências de fatos. O modelo canônico laboviano apresenta elementos sintáticos dessa organização, que consiste em estabelecer discursivamente orações no passado de maneira que a história recupere um determinado ordenamento temporal de ações. De acordo com esse modelo laboviano, os seguintes elementos se articulam nessa construção:

(i) sumário: espécie de resumo da história. Aparece antes do início da sequência de ações, anuncia o assunto e de alguma maneira a razão pela qual a história é contada, isto é, seu ponto;

(ii) orientação: a parte da narrativa em que se identificam personagens, tempo e lugar das atividades narradas, contextualizando, portanto, seus elementos; 
(iii) ação complicadora: as orações narrativas são dispostas em sequência temporal, a partir das quais se conta o que efetivamente aconteceu;

(iv) avaliação: elemento que pode aparecer de forma encaixada, ou em um momento de suspensão do fluxo de ações narradas. Tem a função de dar importância à atitude do narrador em relação a partes específicas da história, além de contribuir para a construção do ponto da história. As avaliações podem ocorrer por meio de recursos expressivos diversos, tais como entonação, inserção de adjetivos ou advérbios, paralelismos sintáticos, dentre muitas outras possibilidades, que aferem dramaticidade à história e funcionam como pista sobre como seus elementos devem ser interpretados pelo interlocutor;

(v) resultado: desfecho para as ações narrativas em que se costura o destino final dos personagens e objetos narrados;

(vi) coda: momento frequentemente final, em que o narrador encerra o fluxo de eventos narrados e retorna ao presente da interação, fornecendo uma nova síntese avaliativa sobre o sentido da história.

Contudo, existe um número considerável de narrativas que não apresentam essa estrutura padrão com os movimentos retóricos descritos por Labov de forma simples e linear. A estrutura da narrativa pode ser mais complexa - ou mais simples - de maneiras diversas.

\section{4) A Difamação}

O Major E. ${ }^{4}$ é militar de carreira, formado na Academia Militar das Agulhas Negras - principal escola de formação de oficiais do Exército Brasileiro. Hoje, com 21 anos de serviço à pátria, ele relata que até mais ou menos o ano de 2012, vivia no armário com medo de ser descoberto. Em diversas oportunidades teve sua sexualidade questionada por superiores dentro da caserna, inclusive perante outros oficiais. Por muitos anos negou ser gay com medo de perseguições veladas (COSTA e BIAR, 2015). Em outras ocasiões, foi achincalhado em conversas nos quartéis e em grupos virtuais de militares em redes sociais. Em 2018, o militar formalizou sua união estável com outro homem e apresentou a documentação na Organização Militar em que servia, garantindo,

\footnotetext{
${ }^{4}$ Embora o militar tenha autorizado a divulgação de seu texto e seu nome real, por questões éticas, optouse por usar o nome fictício "E." para preservar a identidade do participante.
} 
assim, todos os direitos que um militar casado e seu cônjuge possuem. Na oportunidade, não teve maiores problemas em seu quartel e afirma ter sido respeitado plenamente por seus superiores hierárquicos. Menos de um ano após a apresentação da certidão de união estável, o oficial postou uma foto com seu companheiro em seu perfil fechado na rede social Instagram, disponível apenas para pessoas autorizadas por ele mesmo. A imagem foi copiada por algum de seus seguidores - alguém que, até então, o militar acreditava ser seu amigo. Em seguida, a mesma pessoa acessou a página do Departamento Geral de Pessoal do Exército Brasileiro na internet, fez print das informações pessoais e profissionais do militar ${ }^{5}$ (apenas militares têm acesso a tais informações através de senha) e postou em grupos de Whatsapp de militares. Rapidamente, as imagens viralizaram e se espalharam para centenas de outros grupos compostos por militares. Como exemplo do que está sendo dito, seguem algumas imagens a que tivemos acesso:

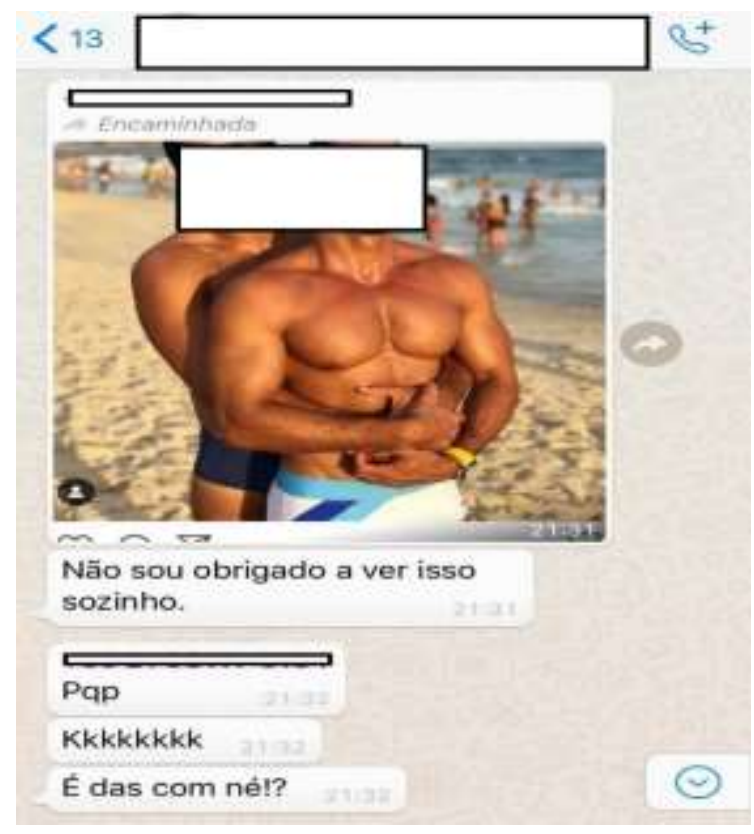

Figura 1

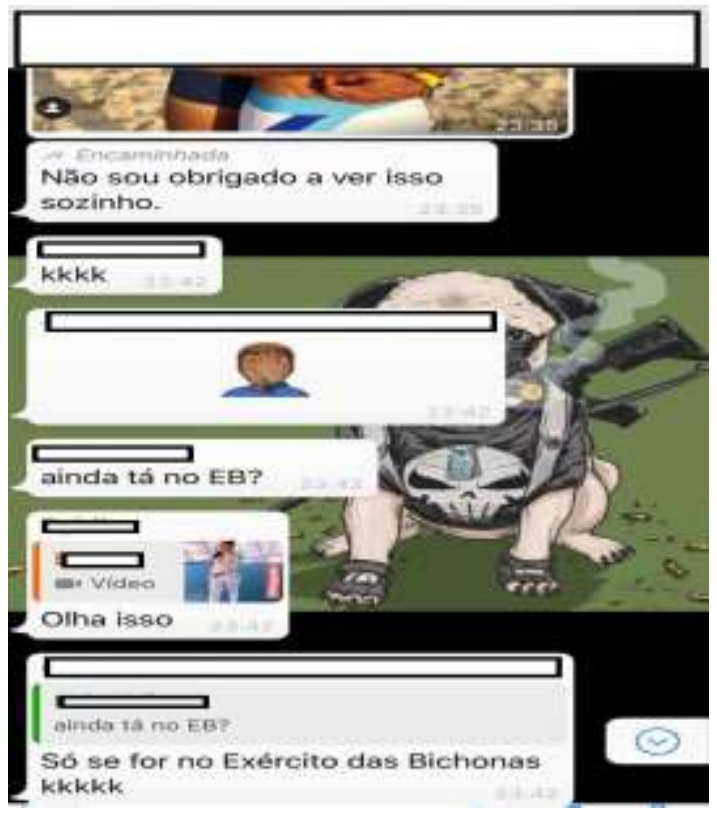

Figura 2

Na figura 1, um oficial comenta que não é obrigado a ver sozinho a imagem de um outro militar abraçado a um homem. Logo em seguida usa um palavrão "pqp" e risadas "kkkkk", indicando uma ridicularização da imagem do Major. Por fim, pergunta se o militar é da Arma ${ }^{6}$ de Comunicações - “É das com, né?". Normalmente, esse

\footnotetext{
${ }^{5}$ Tais informações não serão aqui apresentadas por questões éticas.

${ }^{6}$ As Armas são especializações dentro da carreira militar combatente. As Armas dividem-se em dois grupos: as Armas-Base (Infantaria e Cavalaria) e as Armas de Apoio ao Combate (Artilharia, Engenharia e Comunicações).
} 
questionamento sobre a arma é uma forma de certificar-se que o gay é de outra arma que não a do próprio enunciador.

$\mathrm{Na}$ figura 2, a mensagem da figura 1 é repassada para outro grupo e os interlocutores reforçam o preconceito com comentários que sugerem deboche ("Só se for no Exército das Bichonas") e figuras (um rapaz tapando o rosto por se sentir embaraçado) que confirmam a concepção de que um militar gay é motivo de vergonha para os demais. Com base nesses discursos, entende-se que a assimilação da presença de gays no contexto militar não está acontecendo exatamente da forma natural que o General Villas Boas relata em sua entrevista. O que se percebe é uma resistência por parte de membros da instituição em relação à aceitação institucional imposta pela legislação.
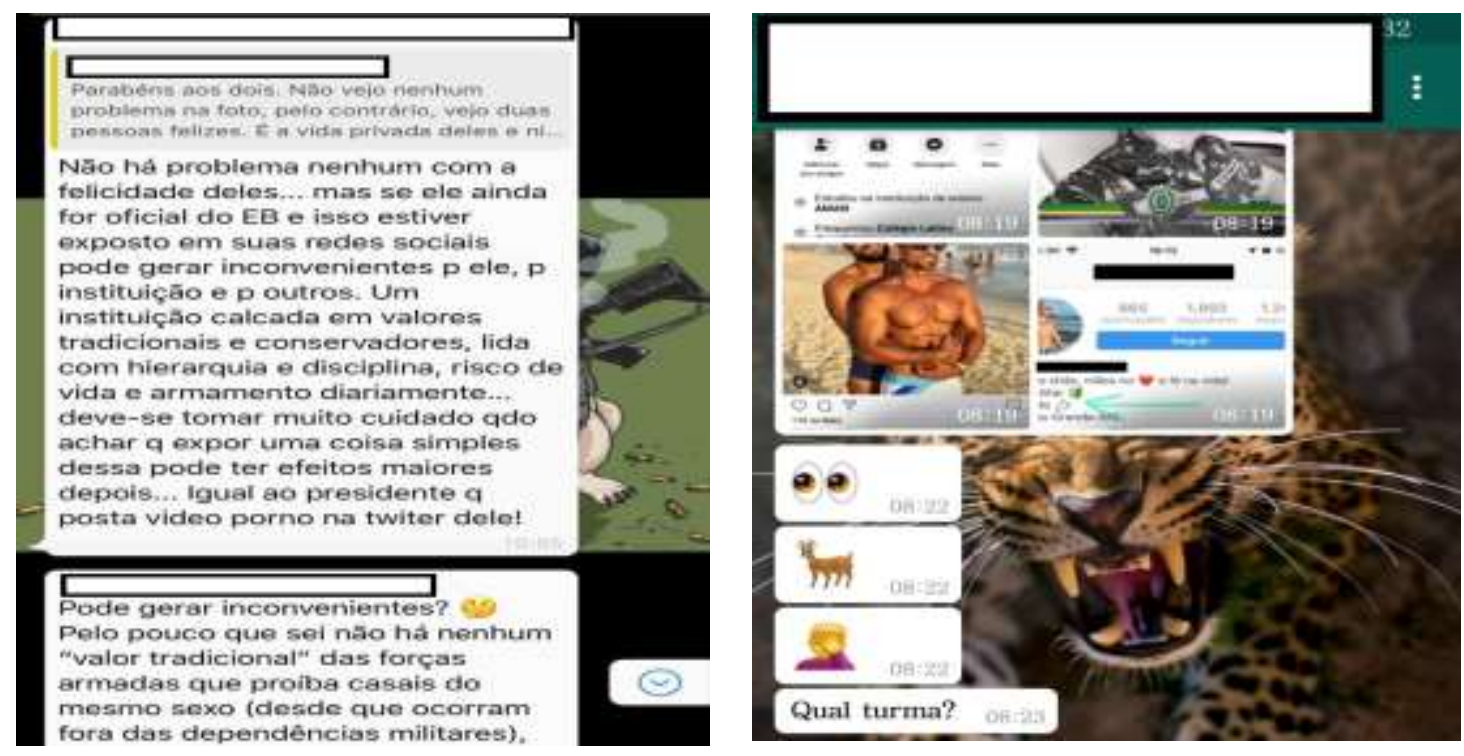

Figura 3

Figura 4

Na figura 3, um militar afirma que o major tem o direito de viver sua vida como quiser. Logo após, seu comentário é respondido por outro militar que defende a concepção de que o Exército é uma instituição calcada em valores tradicionais e conservadores e que ao expor a sua vida íntima homossexual o oficial causa inconvenientes não apenas para a sua imagem, mas para a da instituição como um todo. Sem qualquer argumento sólido além de seu próprio preconceito - o interlocutor assegura que o major deve permanecer no armário a fim de evitar consequências piores.

Por fim, na figura 4, prints de informações que identificam o militar são enviados para um outro grupo seguidos de desenhos de olhos vigilantes, de um veado e de um rapaz envergonhado e, finalmente, da pergunta "qual turma?". 
Todos os prints são exemplos que indicam uma prática recorrente cada vez que um militar sai do armário ou tem sua (homo)sexualidade descoberta. Com o avanço das tecnologias digitais, não foram poucos os casos de militares ridicularizados e expostos na praça pública das redes sociais no intuito de mostrar que quem ousa sair do armário será desmoralizado perante o Exército.

O "machismo milenar", descrito pelo apresentador Bial, e que vem sendo dialogicamente construído nas organizações militares ao longo de sua história, pode ser observado nessas capturas de tela. Os discursos na perspectiva bakhtiniana não são estruturas abstratas, pois carregam a historicidade e as marcas identitárias de seu tempo, de suas formas anteriores e as intenções para formas futuras. Os enunciados, mesmo distantes no tempo e espaço, apresentam uma relação dialógica, seja em seu conteúdo temático, seja em sua estrutura composicional (BAKHTIN, 1979). Para o autor, todos os enunciados da produção linguística no processo de comunicação são dialógicos. Através do conceito de dialogismo, percebe-se que os discursos de preconceito homofóbico presentes no cotidiano militar carregam marcas históricas e concepções culturais da heteronormatividade.

Assim, ao dizer que o Exército é uma instituição calcada em valores tradicionais e conservadores, o que está sendo dito é que homossexuais são pessoas que violam a ética e os bons costumes preservados nas Forças Armadas. Com base no conceito bakhtiniano de dialogismo, percebe-se que não se trata de uma brincadeira, mas de um jogo de poder que coloca o militar homossexual em posição de inferioridade e de marginalização.

Bakhtin (1979) difere a unidade da língua do enunciado. As unidades da língua estão disponíveis, não possuem autor, estabelecem relações semânticas entre si, são completas e não possuem acabamento, ou seja, não requerem uma resposta. Um exemplo de unidade da língua é a palavra bicha no dicionário. Por outro lado, os enunciados são vivos, possuem autores, tem acabamento - completude que permite resposta - e têm sempre destinatários. As unidades da língua são neutras e não possuem juízos de valores. Portanto, a palavra bicha no dicionário, por exemplo, não está carregada de avaliações e apreciações sociais. Entretanto, quando alguém diz que o major está no "Exército das Bichonas", este enunciado está carregado de julgamentos e valores sociais negativos. O enunciado é uma unidade real de sentido, ao passo que a unidade da língua é uma unidade potencial de significação. Para entender que bicha é uma forma ofensiva de se dirigir a uma pessoa homossexual, não basta conhecer a unidade da língua, há que alcançar as relações dialógicas para compreender o que está por trás do sentido prescritivo. 


\section{5) A Resistência}

O caso do Major E., não foi diferente de dezenas de outros militares expostos e vilipendiados em redes sociais. O que seu episódio traz de novo é o fato de o oficial ter decidido se posicionar abertamente sobre a violência simbólica sofrida em sua página no Facebook. Até então, o que sempre ocorria em casos semelhantes era o silêncio. A resposta do militar tomou uma proporção gigantesca; muito maior do que ele mesmo imaginava. Com cerca de 85 mil visualizações e milhares de compartilhamentos, a sua postagem foi assunto de mais de 50 jornais, blogs e revistas do país inteiro. Tais números são indicativos de que tanto a homossexualidade quanto a homofobia nos quartéis ainda são assuntos tratados como tabu e causadores grande repercussão.

Passo agora para a análise do texto extraído de uma postagem aberta no Facebook no dia 12 de março de 2019 do Major E., na qual ele se posiciona em relação à difamação, ao Exército e à sua decisão de sair do armário:

"Há poucos dias postei uma foto com meu companheiro para comemorar 6 anos de relacionamento, foto tirada durante nossas férias numa praia do Rio de Janeiro. Postei em meu perfil privado do instagram, pois estava num momento de muita felicidade e realização e achei por bem externar essa felicidade. Em rede social nada é privado, em poucos momentos depois um dos então "amigos" do Exército Brasileiro que estava em minha rede logo deu um print da postagem privada e divulgou em um grupo de mensagens e daí em diante viralizou a imagem por outros grupos, formados na maioria por militares, particularmente Oficiais do Exército Brasileiro.

Até então eu não estava dando importância, pois aos companheiros de farda que não sabem e que também não lhe diz respeito, sou casado com outro homem desde 2018 e declarei isso no atual quartel onde sirvo no mesmo dia que assinei o documento no cartório. Na época o assunto foi tratado naturalmente sem alarde, sem espanto e sem absurdos. Segui minha vida de casado normalmente, como sempre vivi e vivo, sem nada a esconder. Desculpe se te poupei da "novidade".

Alerta, grande euforia foi causada por militares que jamais imaginavam que um Oficial de Carreira do Exército pudesse assumir sua homossexualidade, ser feliz e realizado no trabalho. Isso foi um soco no estômago dos porcos homofóbicos que nos rodeiam e nos sondam muitas vezes anonimamente, inconformados com a felicidade alheia. Gay? Bicha? Vamos espalhar ao máximo essa foto para fazer com que ele morra de vergonha, ou vamos lacrar no grupo do WhatsApp da turma colocando essa foto bombástica de um Major do Exército sendo abraçado por seu marido. Que choque não é? Uma pena meu querido e infeliz colega de trabalho, você chegou atrasado, sua novidade é tão velha e antiga quanto sua evolução como ser humano, como pessoa ... mas calma ainda dá tempo de você melhorar! Até os últimos momentos de vida podemos nos redimir, vai ser apenas lamentável você esperar até o leito da morte para perceber o quanto da sua vida você perdeu preso a conceitos e preconceitos que em nada vão acrescentar em sua existência. Reflita, ainda há tempo. 
Aos Danieis, Ronaldos, Eduardos e outros nomes que seguem na lista dos que estão divulgando minha fotografia, meu muito obrigado, obrigado por mostrarem as outras pessoas o seu desejo reprimido, sua inveja magoada por minha felicidade e toda a sua pobreza de espírito. Infelizmente ser livre e ser feliz tem seu preço e talvez a coragem e a honestidade que me é exigida por essa liberdade jamais será conseguida por suas almas miseráveis, sinceramente, eu desejo que vocês consigam, se não for nesta que seja na próxima encarnação. É preciso ser muito homem para isso. Talvez você nunca saberá. Vamos aos grupos, a diversão é válida, o humor, o entretenimento, o crescimento o supérfluo... mas querer disseminar o ódio meu amigo? É sério? Com tanta violência e tragédias que já temos que enfrentar ainda temos que administrar nosso convívio com esses espíritos menores que adoram se alimentar do que há de ruim no mundo. Que sentem prazer quando outra pessoa é posta em situação de humilhação e constrangimento. Se isso é que te dá felicidade eu tenho pena da sua alma. No meu dia a dia convivo harmoniosamente com meus colegas de trabalho, o meio militar tem seus preceitos, suas normas e regulamentos, $e$ o Exército Brasileiro tem evoluído junto com a sociedade. Isso é bom, só que muitos militares ficam inconformados com a evolução, com a mudança de pensamento e com o medo de despertar para seus desejos proibidos que até então sempre estiveram inertes e acorrentados em suas mentes reprimidas, exalando homofobia e preconceito. Nesse caso você tem a minha pena. As portas da liberdade foram abertas e é lógico que os primeiros que ousarem atravessar essa trincheira sentirão as sequelas das línguas afiadas, dos olhos que fuzilam o diferente, do medo de não poder mais ser igual. Estou pagando o preço de ser livre, estou cumprindo meu papel, não escondo e muito menos me arrependo, é meu o caminho que percorro, colho os louros e as derrotas que são minhas e mais de ninguém e a minha felicidade jamais será submetida à nenhuma aprovação. Tenha coragem para ser feliz, pois sua covardia é tamanha que ao dar print da tela escondeu até seu nome de usuário. Coisa de macho! Nem parece que passamos pela mesma honrosa Academia Militar das Agulhas Negras onde esconder-se no anonimato era um dos atos mais vergonhosos.

E a você meu caro disseminador de ódio, nunca se esqueça que aqui se planta e aqui se colhe, continue a espalhar a desunião entre as pessoas, continue e semear a raiva e a violência que mais cedo ou mais tarde você terá seu pagamento. Chega a ser cômico e lamentável que um Oficial do Exército perde seu tempo precioso para espalhar que fulano e que ciclano são gays. Um homem adulto, com esposa, filhos, preocupado com outro homem? Que coisa mais estranha não é? Vai se preocupar com o que seu filho está aprendendo na escola, com a felicidade da sua esposa, com a realização da sua família, não perde seu tempo precioso comigo, não vale e pena, já sou casado e feliz, tenho uma linda família que amo e sou muito amado!

Amo men Exército Brasileiro, sou realizado e agradecido pela carreira que abracei. $O$ Exército é um lugar de pessoas honradas, acho que você deveria repensar se está no lugar certo. Como disse anteriormente, as Forças Armadas estão cada vez mais evoluídas perante a sociedade, esse seu pensamento retrógrado só vai te trazer frustração e amargura, liberte-se, permita-se ser feliz. Use seu alma de moleque nos momentos de diversão, em descontração com amigos onde a gente sente falta de ser moleque, não use em atitudes que causam vergonha e olhares de lástima, pois quando se é moleque não temos ainda a noção do que é ser homem.

A foto abaixo é que foi copiada e está circulando pelos grupos. ${ }^{7}$,

\footnotetext{
${ }^{7}$ A imagem foi suprimida aqui por ser a mesma que circulou nos grupos de Whatsapp apresentados anteriormente.
} 
O texto acima, embora não provenha de dados orais - como preconiza a teoria laboviana (1972) -, pode ser entendido como uma narrativa não canônica. Vale ressaltar que na atualidade, as redes sociais são uma forma bastante comum que usamos para contar histórias, criar inteligibilidades sobre a vida social e nós mesmos. Por esse motivo, pego aqui emprestada a teoria de Labov (1972) e seus movimentos retóricos com o intuito de entender como o militar organiza sua experiência e constrói sentidos culturalmente relevantes (BASTOS e BIAR, 2015).

No primeiro parágrafo, o militar faz um sumário, ou seja, uma espécie de resumo da história. Ele anuncia o assunto e a razão pela qual a história é contada, isto é, seu ponto - a difamação em ambientes virtuais ocupados por militares por conta de sua sexualidade. Ainda no mesmo parágrafo, o major oferece algumas orientações a respeito do episódio de discriminação sofrido: identifica personagens (ele mesmo e outros militares do Exército), local (redes sociais virtuais), tempo (há poucos dias) e atividades narradas (“...deu print da postagem privada e divulgou em um grupo de mensagens e daí em diante viralizou a imagem por outros grupos"). Todas essas orientações são necessárias para contextualizar a sequência de eventos.

Ainda no mesmo parágrafo e no seguinte, o major segue com a ação complicadora usando orações narrativas dispostas em sequência temporal, a partir das quais ele conta o que efetivamente aconteceu desde seu casamento em 2018, a apresentação de sua documentação no trabalho, o tratamento recebido no quartel na época e a viralização de sua foto em grupos de Whatsapp .

A avaliação ocorre ao longo do texto, de forma encaixada, com a inserção de adjetivos e outros meios expressivos que qualificam as atitudes e os outros militares que o difamaram ("porcos homofóbicos", "inconformados com a felicidade alheia", "infeliz colega de trabalho" "disseminador de ódio" "sua novidade é tão velha e antiga quando sua evolução como ser humano"). Todas essas expressões adjetivas sinalizam para o leitor do texto como esses acontecimentos devem ser entendidos.

Ao longo do texto é possível perceber que o narrador constrói uma rede de apoio entre ele e a Instituição Exército Brasileiro (“...o assunto foi tratado naturalmente sem alarde, sem espanto e sem absurdos."). É interessante observar como ele descreve os outros militares que o difamaram como tropa inimiga na história narrada, ao mesmo tempo que descreve o Exército Brasileiro como um espaço aberto, evoluído e receptivo às demandas sociais. ("O Exército Brasileiro tem evoluído com a sociedade" "honrosa Academia Militar das Agulhas Negras"), avalia certas pessoas nomeadas por ele (“Danieis, Ronaldos, Eduardos e 
outros nomes que seguem na lista...", "e a você meu caro disseminador de ódio") como vilões. Ou seja, a homofobia é bastante pontual na história narrada - há um "você" a quem ele se dirige diversas vezes. Essa marca de pessoa "você" afasta o Exército Brasileiro da culpa moral. Ou seja, ele se dirige a integrantes da instituição e leva o evento da homofobia a um local específico.

De acordo com Goffman (1959), buscamos sempre nos posicionarmos sob uma luz favorável, e o major faz isso muito bem ao quebrar as expectativas dialogicamente construídas ao logo dos anos sobre ideal de masculinidade na caserna. Apesar do tal "machismo milenar", que tenta excluir das fileiras das Forças Armadas militares homossexuais, o oficial se posiciona sob uma luz favorável ao demonstrar as dificuldades que enfrenta para ser feliz e estar na posição que atualmente ocupa ("estou pagando o preço de ser livre"). O Exército Brasileiro também é construído sob uma luz favorável ("o meio militar tem seus preceitos, suas normas e regulamentos, e o Exército Brasileiro tem evoluído junto com a sociedade."), enquanto seus opositores carregam diversos adjetivos que os posicionam em situação de inferioridade. Em certo ponto, ao mencionar que quem fez o print da foto escondeu seu nome de usuário, o major faz uma ironia que mexe com a identidade masculina (“Coisa de macho!”), pois no imaginário popular, homem não faz fofoca e não se acovarda com seus atos. Cabe observar que a postagem é um texto público e entendendo as relações de poder do narrador com a própria Força Armada, há um cuidado discursivo na construção do Exército Brasileiro que salva a face da instituição militar.

Como em narrativas de histórias militares, percebemos a presença da tropa amiga e da inimiga. O resultado da narrativa, tem como desfecho o sucesso do major, que é descrito como uma pessoa feliz com sua saída do armário e com sua profissão (" $a$ minha felicidade jamais será submetida à nenhuma aprovação", "as Forças Armadas estão cada vez mais evoluídas perante a sociedade", "já sou casado e feliz, tenho uma linda família que amo e sou muito amado"). Por outro lado, os opositores seriam a própria tropa inimiga, que sai derrotada do combate ("aqui se planta, aqui se colhe", "mais cedo ou mais tarde você terá seu pagamento"). Tal interpretação também se apoia na foto que estampa o texto: duas pessoas felizes, sorrindo e demonstrando afeto em uma praia num lindo dia de sol.

Ainda nesse contexto, o militar rompe com o ideal da masculinidade hegemônica e reivindica pra si um espaço de respeito e aceitação por ser um bom profissional e um homem maduro com posicionamentos firmes, enquanto seus irmãos de farda, que teoricamente preencheriam os pré-requisitos de força e masculinidade necessários para a 
carreira militar, são construídos como covardes, mesquinhos, fofoqueiros, sujeitos de almas miseráveis e moleques (“É preciso ser muito homem para isso. Talvez você nunca saberá.").

Por fim, a coda ocorre no último parágrafo, quando o major avalia os efeitos da história - embora tenham tentado desmoralizá-lo, ele é uma pessoa feliz, lutadora e honrada - e retoma o tempo presente (“Amo meu Exército Brasileiro, sou realizado e agradecido pela carreira que abracei. O Exército é um lugar de pessoas honradas, acho que você deveria repensar se está no lugar certo.”, “as Forças Armadas estão cada vez mais evoluídas perante a sociedade", "liberte-se, permita-se ser feliz.", "quando se é moleque não temos ainda a noção do que é ser homem").

\section{6) (In)Conclusões}

O presente trabalho teve como objetivo analisar a construção de um discurso de resistência de um militar que se identifica como gay e sua saída do armário. Para tanto, percorremos o caminho de outras vozes e concepções ideológicas construídas dialogicamente na caserna, que nos permitiram observar como ocorrem os episódios de homofobia no contexto militar em um momento em que o próprio Exército Brasileiro, como instituição pública, busca se adequar às novas leis e demandas sociais. Na contramão das diretrizes da instituição, a discriminação por parte de alguns militares que compõe a Força é iniciada quando indivíduos não apenas constatam a diferença, mas inserem valores morais e passam a se julgar superiores aos outros. A análise dos dados, à luz dos conceitos de dialogismo, heteronormatividade, análise de narrativas, masculinidade hegemônica e epistemologia do armário, aponta que a discriminação contra homossexuais é uma construção socio-histórica-cultural e, para ser combatida, precisa ser ostensivamente problematizada, abordada e desconstruída dentro da instituição.

Concluindo, é possível afirmar que o preconceito presente no contexto militar não ocorre por força da lei, mas provém de tradições socioculturais e se articulam nas interações intrapessoais. Por isso, cabe às Forças Armadas brasileiras abrir espaço para reflexão e entendimentos sobre as práticas homofóbicas e suas consequências, contribuindo assim para transformações sociais sólidas e eficazes que promovam a tolerância e aceitação das diferenças. 


\section{Referências}

BAKHTIN, Mikhail. Estética da Criação Verbal. Tradução Maria Ermantina Galvão G. Pereira. 3. ed. São Paulo: Martins Fontes, 2000. Título Original: Estetika Slovesnogo Tvortchestva. [1979].

BASTOS, Liliana Cabral. Narrativa e vida cotidiana. Revista Scripta, v. 7, n. 14, p. 118 127, $1^{\circ}$ sem, 2004.

Liliana Cabral; BIAR, Liana. Análise de narrativa e práticas de entendimento da vida social. D.E.L.T.A. Documentação de Estudos em Linguística Teórica e Aplicada, v. 31, n. especial, p. 97-125, fevereiro de 2015.

BORRILLO, D. Homofobia: história e crítica de um preconceito. Tradução Guilherme João de Freitas Teixeira. Belo Horizonte: Autêntica Editora, 2010.

CONNELL, Robert William, MESSERSCHMIDT, James W. Masculinidade Hegemônica: Repensando o Conceito. Estudos Feministas, Florianópolis, UFSC, v. 21, n. 1, p. 241-282, jan-abr 2013.

COSTA, Flávia Correia Lima Huber; BIAR, Liana de Andrade. "Já era uma perseguição velada": narrativas de discriminação homofóbica no contexto militar em perspectiva interacionista. In: Scripta. v.19, n.36, p. 409-435, Belo Horizonte, $1^{\circ}$ sem, 2015.

Flávia Correia Lima Huber. "Já era uma perseguição velada": Narrativas de discriminação homofóbica no contexto militar em perspectiva interacionista. 192f. Dissertação (Mestrado em Estudos da Linguagem) - Departamento de Letras, Pontifícia Universidade Católica do Rio de Janeiro. Rio de Janeiro, 2016.

CRISTÓVÃO, Leandro. S. G. Negociações com o armário: homossexualidades e estigma em narrativas de história de vida. 256f. Tese (Doutorado em Estudos da Linguagem) - Departamento de Letras, Pontifícia Universidade Católica do Rio de Janeiro. Rio de Janeiro, 2016.

FABRÍCIO, Branca Falabela. Linguística aplicada como espaço de "desaprendizagem”. In MOITA LOPES, Luiz Paulo da (Org.) Por uma Linguística Aplicada Indisciplinar. São Paulo: Parábola Editora., 2006. p. 45-65.

GOFFMAN, Erving. A representação do eu na vida cotidiana. $17^{\mathrm{a}} \mathrm{ed}$. Petrópolis: Vozes, 2014 [1959]. 233p.

HALL, S. A identidade cultural na pós-modernidade. 11. ed. Trad. T. T. da Silva e G. L. Louro. University Press: DP\&A, 1992.

JESUS, Danie Marcelo de.; LIMA, Ana. Paola. S. Construção identitária de um transhomem em viagem solitária: memórias de um transexual 30 anos depois. In: Jesus, Danie Marcelo, Carbonieri, Divanize; Nigro, Cláudia. (Orgs.). Estudos sobre gênero: identidades, discurso e educação -Homenagem a João W. Nery. 1ed.Campinas: Pontes, 2017, v. 1, p. 75-90.

, Danie Marcelo de. Letramento para a diversidade: dúvidas e incertezas do 
professor em sala de aula. In: Jesus, Danie Marcelo de; Zolin Vesz, Fernando; Carbonieri, Divanize. (Orgs.). Perspectivas críticas no ensino de línguas: novos sentidos para a escola. 1ed.Campinas: Pontes, 2017, v. 1, p. 67-76.

Danie Marcelo de. Cultura da violência: Discurso sobre assassinatos de travestis entre internautas. In: Jesus, Danie Marcelo de; Melo, Glenda Cristina Valim de; Tchalian, Vicente; Júnior, Sara Wagner Pimenta Gonçalves. (Orgs.). Corpos transgressores: política de resistênicia. 1ed.Campinas: Pontes, 2018, v. 1, p. 67-76.

LABOV, William; WALETSKY, Joshua. Narrative Analysis oral versions of personal experience. In: HELM, June. (Org.). Essays on the verbal and visual arts. $1^{a}$ ed. Seattle: University of Washington Press.1967, p. 12-44.

William. The transformation of experience in narrative syntax. In: Language in the inner city studies in the Black English Vernacular. $1^{\mathrm{a}}$ ed. Philadelphia: University of Pennsylvania Press, 1972. 354-396.

LOURO, Guacira Lopes. Corpo, escola e identidade. Educação e Realidade, v.25, n. 2, p. 59-75, jul.-dez., 2000.

MOITA LOPES, Luís Paulo. Discursos sobre gays em uma sala de aula no Rio de Janeiro: é possível queer os contextos de letramento escolar? In: VII Congresso Luso-AfroBrasileiro de Ciências Sociais. Coimbra, 2004. Disponível em <http://www.scielo.br/pdf/rbla/v9n2/07.pdf>. Acesso em 12 nov. 2013.

Luís Paulo. Uma linguística aplicada mestiça e ideológica: interrogando o campo como linguista aplicado. In: _ (Org). Por uma linguística aplicada indisciplinar. São Paulo: Parábola Editora, 2006, p.13-44.

SEDGWICK, Eve.K. [1993] 2007. A Epistemologia do Armário. Cadernos Pagu (28), p.19-54, [1993] 2007.

SEFFNER, Fernando; DUARTE, Gustavo. E quando não há muito mais o que guardar no armário? Homossexualidades e processos de envelhecimento. Bagoas - Estudos gays: gêneros e sexualidades, v. 9, p. 57-82, 2015.

\section{"LAMENTABLEMENTE SER FELIZ TIENE SU PRECIO": SALIDA DEL ARMARIO Y DISCURSO DE RESISTENCIA DE UN MILITAR GAY}

\section{Resumen}

Este artículo analizará el discurso de resistencia de un militar gay con el objetivo de discutir las estructuras culturales que actúan en la construcción de la homofobia en el Ejército. El análisis se basa en el marco teórico del análisis de narrativa, dialogismo, masculinidad hegemónica y epistemología del armario. El objetivo es problematizar el choque entre la aceptación legal de la presencia de homosexuales en los cuarteles y el rechazo de colegas de uniforme.

\section{Palabras-clave}


Homofobia. Militar. Armario. Discurso. Masculinidades. 